\title{
SOCIAL AWARENESS \\ (Discourse Analysis of Novel Dalang Galau by Sujiwo Tejo)
}

\author{
Adi Ari Hamzah \\ Magister Students of Universitas Islam Negeri Sunan Kalijaga Jogjakarta \\ email: adiarihamzah@gmail,com
}

\begin{abstract}
Sujiwo Tejo is an Indonesian novel writer who is considered a writer as well as a contemporary humanist. The themes in his novels always raise social, political or religious issues. The novel "Dalang Galau Ngetwit" is one of his works that raises social themes and brotherhood among religious communities, because these issues are realized increasingly fading with a variety of things that lie behind them. In the novel "Dalang Galau Ngetwit" Sujiwo Tedjo tries to give an understanding to the community about the importance of kinship without seeing what religion it adopts, helping one another and always living in harmony. In this novel's work, the writer sees social injustice in the text of Sujiwo Tejo's novel. To assess the work of the novel, the writer uses Teun A Van Dijk's Discourse Analysis which divides the discourse into three levels: macro structure, Superstructure and Microstructure. The problem formulated in this paper is, what is the meaning of the message conveyed by Sujiwo Tedjo through the novel "Dalang Galau Ngetwit" in seeing the social conditions of the community to religious harmony and how this novel is able to describe the attitude of the community in national and state activities towards the problem of changes that exist in the cultural conditions in Indonesia.
\end{abstract}

Keywords: Social Awareness, Discourse Analysis, Novel

\section{INTRODUCTION}

The word social cannot be separated from the existence of a process towards development. The occurrence of social change can be seen as a concept that includes and points to the social changes that occur in society. Such as changes that occur at various levels of community life. Changes that occur in social life cannot be separated from thoughts and desires for the advancement of the community.

The occurrence of social change is caused by changes in the elements that maintain the balance of society. For example changes in geographical, technological, economic or cultural elements. Conditions like these have led to changes in other aspects of social life. As in the novel "Dalang Galau Ngetwit" which the author will examine the narrative text in it refers to the social conditions that occur in the current era. Changes such as social inequality, religious discrimination, to the desecration of the self-esteem of youth, have resulted in the decline of the intellectual generation.

Through a novel, the messages conveyed are more fictional and deep to the reader. Starting from an imaginative and relative message, usually someone after 
reading, quotes some words of wisdom, such as motivational words and romantic words and uploads them to social media. so that the message conveyed by a novel is no longer fictitious, but social in nature because it is disseminated through social media.

Novels are a medium that can be used to convey various messages by writers to their readers. Every writer has their own way of telling stories because they are based on life experiences and different backgrounds. Such as social factors, geography, culture and even politics. Then the writer is interested in studying the social messages in the text of the novel "Dalang Galau Ngetwit" by Sujiwo Tedjo using Teun A Van Dijk's theory of Discourse Analysis.

\section{SOCIAL THEORY}

The social movements that have occurred in the community groups in the end give rise to social class, social awareness and lead to social change. Karl Marx explained these concepts in almost all of his works. In his works Marx does not define social class explicitly. As quoted in The Marx-Engels Reader by Robert C. Tucker (1972) at the beginning of The Communist Manifesto, Marx says:

"The history that comes from society which remains until now is the history of class struggle. Free men and slaves, aristocrats and commoners, masters and servants, corporate leaders and confused people, in one language, oppressor and oppressed, always at odds with each other, going on incessantly in one sometimes hidden, sometimes - sometimes open, a struggle which ends each time, both in a revolutionary reconstitution of society in general, and in the general collapse of these bickering classes. "

According to Marx, quoted by Smelser, the destruction of feudalism that was born and the development of capitalism and modern industry has resulted in the splitting of society into two opposing classes, namely the bourgeoisie (bourgeoisie) which has the means of production and the proletariat (proletariat) which does not have the means of production.

So actually Marx did not define and analyze in depth the concept of social class, but Marx only described the situations and conditions that occurred at that time, at which time society was divided into two groups based on ownership and non-ownership of the means of production. Interpreting Marx's thoughts, Kamanto Sunarto (2000) argues that with the development of the industry, the owners of the means of production are increasingly applying the division of labor and using machines as a substitute for labor so that competition for jobs among workers increases and labor wages decrease. It is this exploitation and oppression of the proletariat that causes them to have class consciousness and to unite increasingly against the bourgeoisie.

Then Marx predicted that at one time the increasingly integrated workers and through a class struggle would succeed in wresting the means of production 
from the bourgeoisie and then establishing a classless society because private ownership of the means of production had been abolished. ${ }^{1}$

\section{SOCIAL AWARENESS}

After the formation of classes in capitalist society, class consciousness will emerge about the interests of their classes. What is meant by class consciousness according to Marx as quoted in Doyle 1986 is a subjective awareness of the objective class interests which they share with other people in a similar position in the production system. The concept of interest refers to the actual material resources needed to meet an individual's need or desire. Thus, Doyle gives an example that the interests of the capitalist class lie in increasing profits, while the interests of the proletariat narrowly include wage increases, while broadly covering control over a wider production process. $^{2}$

According to Marx as reported by Giddens 1986 that consciousness is rooted in human praxis, which in turn is social. This is the meaning of being said, that 'it is not consciousness that determines people's existence, but on the contrary, their social life determines their consciousness. ${ }^{3}$

The emergence of false consciousness due to the influence of ideology developed to support the dominant class and existing structures according to Marx as quoted by Doyle can be replaced by true class consciousness by means of shared misery. Marx focuses the emergence of a correct class consciousness with his analysis on the developments which take place within the proletariat in the industrial areas of the city.

The reason is that because they work together in a factory in inhuman conditions and live side by side with each other (between workers of one factory) as neighbors in one city as well, the proletariat is becoming aware of its common suffering and economic destitution. In short, their concentration in one place allows communication networks to form and generates shared awareness.

\section{AUTHOR PROFILE OF NOVEL}

Sujiwo Tedjo was born in the village of Ambula, Jember, East Java, August 31, 1962. He inherited the talent for puppetry from his father, Soetodjo. According to him, writing books remains a constitutional part of his work as puppeteers. To be able to stage wayang plays, a puppeteer must at least master the basics of fine arts, music, acting, and literature. Writing a book for Sujiwo Tedjo, known as the crazy puppeteer, is performing through one of the elements of puppetry.

\footnotetext{
${ }^{1}$ Sunarto, Kamanto. Pengantar Sosiologi. Edisi kedua. (Jakarta: FE UI, 2000), 92.

${ }^{2}$ Doyle Paul Johnson, Teori Sosiologi Klasik Dan Modern. Terj. Robert M. Z. Lawang (Jakarta: Gramedia, 1986), 150.

${ }^{3}$ Giddens, Anthony. Kapitalisme Dan Teori Sosial Modern suatu analisis karya tulis Marx, Durkheim dan Max Weber. Terj. Soeheba Kramadibrata (Jakarta: UI Press, 1986), 50.
} 


\section{SYNOPSIS OF NOVEL}

"Dalang Galau Ngetwit" is a short story written by the puppeteer, Sujiwo Tedjo, which contains 140 pages which are the result of ideas that surfaced on social media and on his tweets. The puppeteers are known to be eccentric in writing scripts that are educational and piercing to awaken readers in everyday life with simple language for fans of the Sujiwo Tedjo book.

Sujiwo Tedjo also raised awareness about youth and invited people to have a more knight spirit and be aware of wise actions in carrying out their lives as stated in his novel "Dalang Galau Ngetwit". When Sujiwo Tedjo wrote the book "Dalang Galau Ngetwit", it became several chapters that may be related to one another. His views on love, God, destiny, society, religion and even life make readers interested in this nonsensical language. However, if the reader can understand more deeply the meaning he wrote, he will be able to reap the essence of each sentence.

Sujiwo's view on religious issues such as 'insulting God is not necessary to step on the holy book, we are afraid that tomorrow not eating, it is insulting God' means that religious issues do not need to be exaggerated or ridicule even discriminating against God is tantamount to insulting God's creation. This crazy puppeteer even told me that when he had a problem, then look at the vast ocean, because with that the problem that is considered broad is nothing compared to the stretch of the ocean that seems endless.

\section{NOVEL DATA ANALYSIS}

The analytical method used in discussing this novel is the Teun A Van Dijk analysis model. The analysis model observes three things, namely text, social cognition, and social analysis. However, the author will only discuss text and social analysis to make it more relevant to the title of the article and issues related to social injustice.

According to Teun A Van Dijk's analytical framework, there are three things that can be observed through Sujiwo Tejo's novel "Dalang Galau Ngetwit", namely the structure of text and social analysis.

Table 1: Text Analysis and Social Analysis Framework

\begin{tabular}{|l|c|}
\hline \multicolumn{1}{|c|}{ Method Structure } & Method Structure \\
\hline $\begin{array}{l}\text { Text: Analyzing how the discourse strategy used to } \\
\text { describe the contents of the novel and social messages } \\
\text { against the oppression that occurs in the novel's narrative }\end{array}$ & Critical \\
leads to the depiction of reality & \\
\hline $\begin{array}{l}\text { Social Analysis: Analyzing how the discourse is developing } \\
\text { in society. The construction process of a person or event is } \\
\text { described }\end{array}$ & Literature Review \\
\hline
\end{tabular}


According to Van Dijk, all texts can be analyzed even though they are confined to various elements, all of these elements are one unit, interconnected and support one another. ${ }^{4}$ Text structure, in observing the structure of the text, is seen from several levels, each part supporting each other. Teun A Van Dijk divides it into three levels, namely macro structure, superstructure, and micro structure.

Macro structure is a global meaning of a text that can be observed from the topic or theme raised by a text. Superstructure is the framework of a text, such as the introduction, content, closing, and conclusion. Micro structure is the local meaning of a text which can be observed from the choice of words, sentences and styles used by a text.

\section{ANALYSIS OF INJUSTICE IN NOVEL}

In the novel "Dalang Galau Ngetwit" the explanation of the text is the structure of the text. Based on Teun A Van Dijk's theory, the text consists of three analyzed structures, namely macro structure, superstructure, and micro structure. To see how the novel expresses through certain descriptions using the Critical Linguistic method, the following is the discussion: First, the macro structure of things observed in this structure is thematic or thematic.

It is clear that the text of the novel is the author's attitude towards a generation of people with so many social and religious problems, accompanied by facts and also an analysis of the text relating to culture. Second, the superstructure sees the concept of writing. It is observed how the sequence of novels in the concept in the form of text narrative becomes the focus of study. Judging from the elements of the concept of writing the novel "Dalang Galau Ngetwit" has a systematic concept. The views that are in the first part of the next idea provide facts that influence the point of view. Third, in the microstructure reading, there are four focuses of reading.

From the semantic, syntactic, stylistic, and rhetorical side analysis to facilitate the explanation, the writer presents each angle as follows: (a) Sentence forms contained in the novel are active sentences which in the statement "All just undergo destiny. Some are destined to surrender, some are destined to try. There are also those who are destined not to believe that all are just living their destiny". ${ }^{5}$ First, semantics in the microstructure of meaning that you want to emphasize in the use of this structure is Teun A Van Dijk's discourse scheme which is called the relationship between sentences.

Second, syntax reading syntax to find out how opinions are conveyed. Meanwhile, the stylistics of observing the words used by Sujiwo Tedjo in this case include literature. Second, the rhetorical microstructure in the author's rhetorical observations about the style of delivery. Is it through graphics, expressions, and

\footnotetext{
${ }^{4}$ Alex Sobur, Analisis Teks Media Suatu Pengantar untuk Analisis Wacana, Analisis Semiotik, dan Analisis Framming (Bandung: Remaja Rosdakarya, 2006), 73-74.

${ }^{5}$ Sujiwo Tejo, Dalang Galau Ngetwit (Bandung: Mizan Media Utama (MMU), 2013), 1.
} 
metaphors. The style of delivering discourse in the book "Dalang Galau Ngetwit" by Sujiwo Tejo uses metaphorical sentence style, is synonymous and tends to use language of connotation and interpretation.

The discourse used adheres to a Marxist ideology that is free and responsible and functions as social control. The author wants to convey to the reader about the interpretation of the text in the novel "Dalang Galau Ngetwit" to all groups of society. If presented in the table will be illustrated as follows:

Table 2: Text Analysis Framework

\begin{tabular}{|l|l|l|}
\hline $\begin{array}{l}\text { Discours } \\
\text { e } \\
\text { structure }\end{array}$ & Element & \multicolumn{1}{|c|}{ Findings } \\
\hline $\begin{array}{l}\text { Macro } \\
\text { Structure }\end{array}$ & $\begin{array}{l}\text { Topic } \\
\text { theme }\end{array}$ & $\begin{array}{l}\text { The social message of the novel "Dalang Galau } \\
\text { Ngetwit" by Sujiwo Tedjo }\end{array}$ \\
\hline $\begin{array}{l}\text { Super } \\
\text { Structure }\end{array}$ & $\begin{array}{l}\text { Schematic } \\
\text { / Flow }\end{array}$ & $\begin{array}{l}\text { Opening: The social message of the novel "Dalang } \\
\text { Galau Ngetwit against social oppression and } \\
\text { discrimination between religions. } \\
\text { Content: Novels in each sub-theme of the text construct } \\
\text { social, religious and cultural thoughts and messages. } \\
\text { Closing: An appeal to socio-culture and to each } \\
\text { generation to be more critical in seeing the conflicts that } \\
\text { occur in the midst of society. }\end{array}$ \\
\hline Backgroun \\
d
\end{tabular} \begin{tabular}{l}
$\begin{array}{l}\text { Sujiwo Tedjo emphasized the point of the heart that is } \\
\text { capable of thinking independently, saying } \\
\text { independent and entertaining, and flicking } \\
\text { independently and to achieve that what he has is of } \\
\text { course more than just confusion but an enlightenment. }\end{array}$ \\
\hline
\end{tabular}




\begin{tabular}{|l|l|l|}
\hline $\begin{array}{l}\text { Micro } \\
\text { Structure } \\
\text { (Semanti } \\
\text { cs) }\end{array}$ & Detail & $\begin{array}{l}\text { This goal is for the public and readers to get } \\
\text { information in accordance with what Sujiwo Tedjo } \\
\text { wrote to have the same perception as what he wants } \\
\text { to emphasize in the text / discourse. }\end{array}$ \\
\hline
\end{tabular}

\begin{tabular}{|l|l|l|}
\hline & Mean & $\begin{array}{l}\text { The elements of the discourse of intent, almost the same } \\
\text { as the elements of detail in the details, information } \\
\text { which is beneficial to the author will be described in } \\
\text { lengthy detail. }\end{array}$ \\
\hline $\begin{array}{l}\text { Micro } \\
\text { Structure }\end{array}$ & $\begin{array}{l}\text { Sentence } \\
\text { Form }\end{array}$ & $\begin{array}{l}\text { The end goal is for the public to receive the information } \\
\text { presented and can benefit the author }\end{array}$ \\
\hline Syntax) & Coherence & $\begin{array}{l}\text { Active Sentences such as "Data is a matter of how you } \\
\text { translate other people, but information is how you } \\
\text { translate yourself in life" }\end{array}$ \\
\hline $\begin{array}{l}\text { Micro } \\
\text { Structure } \\
\text { (Stylistic) }\end{array}$ & Graphic & $\begin{array}{l}\text { Affirmative word; } \\
\text { Do you need one more lesson? namely character } \\
\text { lessons that shape children's character not lessons, but } \\
\text { concrete examples of parents, TV broadcast teachers, } \\
\text { officials, traffic culture and others. }\end{array}$ \\
\hline
\end{tabular}

\section{SOCIAL CONTEXT ANALYSIS}

Social analysis deals with forms that influence the use of language for the formation of a discourse. Like settings, situations, social events and conditions that occur in texts in a novel and certain social contexts, a discourse can be understood, read, and analyzed.

The author analyzes this social context, it is divided into two parts, namely: First, the practice of social awareness, the word is a term used in the text of the book "Dalang Galau Ngetwit" by Sujiwo Tedjo. The choice of words in the text that are related to the author's experiential value or experience reflects the author's content, knowledge, and beliefs. For example, the choice of words used by the author in the book "Dalang Galau Ngetwit" can be seen from the form of social awareness. This is emphasized in the text:

Do you need one more lesson? namely character lessons that shape children's character not lessons, but concrete examples of parents, TV broadcast teachers, officials, traffic culture and others.

From the text above, it is clear how the practice of social awareness of the majority of people experiences unconsciousness in the circle of society. Second, networks influence discourse, networks that influence discourse on novel attitudes towards readers in Indonesia, namely all elements of society and for youth to critically see 
the condition of their surroundings. The media should be used as a means of producing discourse that is effective in disseminating it so that the problem of discrimination in social society can be quickly accepted among the general public.

\section{CONCLUSION}

After analyzing and explaining the concepts and descriptions of the previous section. So in the conclusion part takes from the focus of the writing objectives as follows; (1) The text discourse in the novel "Dalang Galau ngetwit" by Sujiwo Tejo is seen from the reading of Teun A Van Dijk's text, among others: (a) This text is able to describe semantics or meanings that are well emphasized, such as description of the background and overall details text. (b) In choosing words or lexicons, this novel uses words that contain affirmations in social messages as well as using correlative affirmations such as "and" "still". (c) This text constitutes the four elements of Teun A Van Dijk's model discourse that help construct. (2) The reading of the social context contained in the text of the novel "Dalang Galau Ngetwit" "Do you still need one more lesson? that is, character lessons that shape children's character are not lessons, but concrete examples of parents, TV broadcast teachers, officials, traffic culture and others ". The discourse that developed in society at that time (social context) was the novel "Dalang Galau Ngetwit" which describes the practice of collective awareness of society.

\section{REFRENCES}

Tejo, Sujiwo. Dalang Galau Ngetwit. Bandung: Mizan Media Utama (MMU). 2013. Sobur, Alex. Analisis Teks Media Suatu Pengantar untuk Analisis Wacana, Analisis Semiotik, dan Analisis Framming. Bandung: Remaja Rosdakarya, 2006.

Giddens, Anthony. Kapitalisme Dan Teori Sosial Modern suatu analisis karya tulis Marx,

Durkheim dan Max Weber Terj. Soeheba Kramadibrata. Jakarta: UI Press, 1986. Sunarto, Kamanto. Pengantar Sosiologi. Edisi kedua. Jakarta: FE UI, 2000. 